\title{
Occurrence and Molecular Characterization of Strobilurin Resistance in Cucumber Powdery Mildew and Downy Mildew
}

\author{
H. Ishii, B. A. Fraaije, T. Sugiyama, K. Noguchi, K. Nishimura, T. Takeda, T. Amano, and D. W. Hollomon
}

First, third, fourth, and fifth authors: National Institute for Agro-Environmental Sciences, Tsukuba, Ibaraki 305-8604, Japan; second and
eighth authors: Department of Agricultural Sciences, University of Bristol, Long Ashton, Bristol BS18 9AF, UK; and sixth and seventh
authors: ZEN-NOH Agricultural R\&D Center, Hiratsuka, Kanagawa 254-0016, Japan. Accepted for publication 13 August 2001.

\begin{abstract}
Ishii, H., Fraaije, B. A., Sugiyama, T., Noguchi, K., Nishimura, K., Takeda, T., Amano, T., and Hollomon, D. W. 2001. Occurrence and molecular characterization of strobilurin resistance in cucumber powdery mildew and downy mildew. Phytopathology 91:1166-1171.

Between 1998 and 1999, control failure of powdery mildew (Podosphaera fusca) and downy mildew (Pseudoperonospora cubensis) by the strobilurin fungicides azoxystrobin and kresoxim-methyl was observed in cucumber-growing areas of Japan. Results from inoculation tests carried out on intact cucumber plants and leaf disks clearly showed the distribu-

and their sequences analyzed to elucidate the molecular mechanism of resistance. A single point mutation (GGT to GCT) in the cytochrome $b$ gene, resulting in substitution of glycine by alanine at position 143, was found in resistant isolates of downy mildew. This substitution in cytochrome $b$ seemed to result in high resistance to strobilurins in this pathogen. The same mutation was found in some but not all resistant isolates of powdery mildew. This study suggests that a mutation at position 143 in the target-encoding gene, resulting in an amino acid substitution, was probably a major cause of the rapid development of high strobilurin resistance in these two pathogens.
\end{abstract} tion of pathogen isolates highly resistant to azoxystrobin and kresoximmethyl. Fragments of the fungicide-targeted mitochondrial cytochrome $b$ gene were polymerase chain reaction amplified from total pathogen DNA
Additional keywords: cross-resistance, cytochrome $b$, fungicide, fungicide resistance, mitochondrial DNA, point mutation.
Strobilurin fungicides, such as azoxystrobin and kresoximmethyl, developed from naturally occurring products (e.g., strobilurin A, found in mushrooms) are used in many countries, because they have a broad spectrum of control against a large number of pathogens on various crops (24). These fungicides are not persistent in the environment, expected to be safe to nontarget species, and highly suitable for inclusion in integrated pest management (IPM) programs.

Strobilurin fungicides have a novel mode of action. They bind to the subunit protein of cytochrome $b c_{1}$ complex of the electron transport chain located in the inner-mitochondrial membrane, thereby inhibiting fungal respiration (17). However, as experienced with benzimidazoles, it is well known that site-specific fungicides generally possess a high risk of resistance development if resistant isolates of the pathogen are not impaired in their ability to survive and multiply in the agricultural environment.

Field resistance to strobilurin fungicides was first reported in wheat powdery mildew populations in northern Germany in 1998 (1,3). In Japan, kresoxim-methyl and azoxystrobin were officially registered in December 1997 and April 1998, respectively. Most cucumber growers followed the manufacturers' usage recommendation and applied their products only a couple of times per crop in alternation with other fungicides, which possess different modes of action. However, soon after the introduction of strobilurins, control failure of powdery mildew (Podosphaera fusca (Fr.) U. Braun \& N. Shishkoff = Sphaerotheca fusca (Fr.) S. Blumer) by these fungicides was frequently reported in cucumbergrowing areas. Subsequently, in 1999, reduced efficacy of strobilurin fungicides was also claimed in cucumber downy mildew (Pseudoperonospora cubensis (Berk. \& M. A. Curtis) Rostovzev).

Corresponding author: H. Ishii; E-mail address: hideo@niaes.affrc.go.jp

Publication no. P-2001-1005-01R

(C) 2001 The American Phytopathological Society
To determine the cause of the reported rapid decline in strobilurin fungicide efficacy, the authors examined strobilurin sensitivities of powdery and downy mildew isolates collected from cucumber greenhouses or fields where control failure was observed. Polymerase chain reaction (PCR) amplification of fragments of mitochondrial cytochrome $b$ gene from sensitive and resistant isolates of both pathogens and subsequent sequence analyses indicated the possible molecular mechanism of resistance. Brief results of this work have already been reported $(7,8)$.

\section{MATERIALS AND METHODS}

Compounds. Commercial formulations of azoxystrobin $(20 \%$ flowable) and kresoxim-methyl (41.5\% flowable) were purchased. Technical grade of azoxystrobin and kresoxim-methyl was kindly supplied by Zeneca K. K. Agrochemicals (Tokyo) and BASF Japan Ltd. (Tokyo), respectively.

Isolation and maintenance of pathogens. Cucumber powdery mildew. In May 1999, sporulating leaves were collected from cucumber plants commercially grown in two greenhouses in Shimodate, Ibaraki, Japan. In one greenhouse (house A), azoxystrobin was used for powdery mildew control only once in 1998 and three times, alternatively with unrelated fungicides, in 1999, before sampling of the pathogen. The efficacy of azoxystrobin had already been lost when samples were taken. In another greenhouse (house B), strobilurin fungicides were never used for the control of powdery mildew, although the grower sprayed azoxystrobin once in early 1999 for downy mildew control. House B was approximately $5.5 \mathrm{~km}$ away from house A. Mass isolation of conidia from leaves was carried out using a swab. Each isolate, derived from a single leaf sampled randomly in greenhouses, was inoculated and maintained on detached healthy leaves of cucumber (cv. Shin Suyo Tsukemidori), kept in petri dishes at $20^{\circ} \mathrm{C}$ under fluorescent light at 12-h intervals. Two isolates from house $\mathrm{A}$ and five isolates from house B, thus obtained, were used for fungicide 
sensitivity tests. The reference sensitive isolate, K-7-2, stocked in ZEN-NOH Agricultural R\&D Center, Kanagawa, Japan, and another sensitive isolate, Melon 1, obtained from melon in Miyazaki, Japan in February 2000, were also included in the tests.

Cucumber downy mildew. In July 1999, cucumber leaves bearing zoosporangia of the pathogen were collected from a field in Sanbu, Chiba, where control failure of downy mildew with both azoxystrobin and kresoxim-methyl was observed. Zoosporangia were mass isolated from a diseased single leaf, inoculated, and maintained on potted cucumber plants grown in a phytotron. The isolates $\mathrm{R}$ and $\mathrm{S}$ thus obtained were maintained on detached healthy leaves of cucumber kept in moist petri dishes at $20^{\circ} \mathrm{C}$ under intermittent fluorescent light in the later part of the study. One resistant isolate, A1-9, was derived from a commercial cucumber greenhouse in Akeno, Ibaraki where heavy mildew attack was seen in the autumn of 1999. Another resistant isolate, MAZ-1, was obtained from an experimental greenhouse at Miyazaki Agricultural Experiment Station in which strobilurin fungicides had been tested, although no failure of downy mildew control was noticed. The reference sensitive isolate FS from ZEN-NOH Agricultural R\&D Center was also included in the study.

Sensitivity tests. Cucumber powdery mildew. Sensitivity of isolates to azoxystrobin and kresoxim-methyl was determined by leaf disk (A) and foliar spray (B) tests.

Test A: the method described by Schepers (18) was used in this study. Leaf disks ( $1 \mathrm{~cm}$ in diameter), cut with a corkborer from healthy cucumber cotyledons, were placed on moist filter paper in a petri dish and the upper side of disks was inoculated with powdery mildew isolates by dropping conidia through a settling tower. Cell culture dishes (Multidish, 6 wells; Nalge Nunc International, Roskilde, Denmark) were used to float inoculated disks on fungicide suspensions or solutions at five disks per well. When the commercial formulation was employed, concentrations used were $0,0.01,0.1,1,10$, and $100 \mu \mathrm{g} \mathrm{ml}^{-1}$ of active ingredient (a.i.) for azoxystrobin and $0,0.01,0.1,1.4,13.8$, and $138 \mu \mathrm{g} \mathrm{ml}^{-1}$ a.i. for kresoxim-methyl, where the highest concentration was equivalent to that recommended for practical use. Technical grade of both fungicides also was used at $0,0.001,0.01,0.1,1$, and $10 \mu \mathrm{g} \mathrm{ml}^{-1}$ a.i. after dissolving in dimethyl sulfoxide (DMSO) and diluting with distilled water. The concentration of DMSO in the solution never exceeded $1 \%$. At 8 to 10 days after inoculation, mildew development on each leaf disk was recorded, using the following scale: $0=$ no visible mildew development, $1=0$ to $5 \%, 2=6$ to $25 \%, 3=26$ to $50 \%, 4=51$ to $75 \%$, and $5=>76 \%$ of disk surface covered with mildew. Disease severity (DS) was calculated as $[(5 A+4 B+3 C+2 D+E) / 5 F] \times 100$, where $A, B, C, D$, and $E$ are the number of leaf disks corresponding to the scales, $5,4,3,2$, and 1 , respectively, and $F$ is the total number of leaf disks assessed. Control (\%) of individual fungicides was calculated as [(DS on untreated leaf disks - DS on treated leaf disks)/DS on untreated leaf disks] $\times 100$.

Test B: Whole leaves of 2-week-old potted cucumber plants, grown at $25^{\circ} \mathrm{C}$ in a phytotron, were sprayed with the commercial formulation of azoxystrobin at various concentrations. Distilled water was used as a control. Three replicate plants were prepared for each treatment. After air drying, plants were inoculated by spraying conidial suspensions $\left(\approx 2.5 \times 10^{5} / \mathrm{ml}\right.$ of distilled water $)$ of powdery mildew isolates, then kept at $25^{\circ} \mathrm{C}$ under intermittent fluorescent light. Assessment of disease development on each true leaf was performed in a similar manner to that described above (test A) 10 days after inoculation, and control (\%) of each fungicide was calculated.

Cucumber downy mildew. Foliar spray tests were employed. The lower surface of whole leaves of 2- to 3-week-old potted cucumber plants, three for each treatment, grown at $25^{\circ} \mathrm{C}$ in a phytotron, were sprayed with the commercial formulation of azoxystrobin or kresoxim-methyl at recommended concentrations. Distilled water was used as a control. After air drying, the leaves were spray-inoculated with the zoosporangial suspensions $(\approx 1$ to $2 \times$ $10^{5} / \mathrm{ml}$ of distilled water) of downy mildew isolates, kept at $20^{\circ} \mathrm{C}$ in a dew chamber for $24 \mathrm{~h}$, and incubated at $25^{\circ} \mathrm{C}$ in a phytotron. Disease development on each leaf was recorded 7 days after inoculation using the same scale and DS calculated as described above. Control $(\%)$ of individual fungicides was calculated as [(DS on untreated leaves - DS on treated leaves)/DS on untreated leaves] $\times 100$.

Isolation of total DNA. Conidia or zoosporangia collected from leaves were lyophilized and ground with a mortar and pestle using glass beads with liquid nitrogen. The powder was suspended in extraction buffer containing $10 \mathrm{mM}$ Tris- $\mathrm{HCl}(\mathrm{pH} 7.5), 50 \mathrm{mM}$ EDTA, $100 \mathrm{mM} \mathrm{LiCl}$, and $0.2 \%$ mercaptoethanol and heated at $65^{\circ} \mathrm{C}$ for $30 \mathrm{~min}$. The suspensions were centrifuged at $13,000 \mathrm{rpm}$ for $5 \mathrm{~min}$, and the supernatants collected, treated with $10 \mu \mathrm{g}$ of RNase, incubated at $37^{\circ} \mathrm{C}$ for $1 \mathrm{~h}$, and subsequently phenolchloroform-isoamyl alcohol $(25: 24: 1)$ extracted three times. The aqueous layers were extracted with chloroform-isoamyl alcohol (24:1) twice and isopropyl alcohol was added to form clots of DNA. The pellet of DNA was collected by centrifugation, washed with $70 \%$ cold ethanol, and resuspended in Tris-EDTA (TE) buffer containing $10 \mathrm{mM}$ Tris- $\mathrm{HCl}$ and $1 \mathrm{mM}$ EDTA, pH 8.0 after drying.

PCR experiments. Based on highly conserved regions of cytochrome $b$ amino acid sequences in fungi, Fraaije, B. A. designed the following PCR primers: RSCBF1 5'-TATTATGAGAGATGTAAATAATGG-3' and RSCBR2 5'-AACAATATCTTGTCCAATTCATGG-3'. The primers were synthesized with a DNA Synthesizer Expedite 8909 (Applied Biosystems, Foster, CA) at ESPEC Oligo Service Corp., Tsukuba, Japan. PCR reaction mixtures contained total DNA, $1.5 \mathrm{mM} \mathrm{MgCl} 2,200 \mu \mathrm{M}$ each dNTP, and 2.5 units of Taq DNA polymerase (Nippon Gene, Toyama, Japan). PCR reactions were performed in a Program Temp Control System PC707-05 (ASTEC, Fukuoka, Japan) programmed for $2.5 \mathrm{~min}$ at $94^{\circ} \mathrm{C}$, followed by 40 cycles of $0.5 \mathrm{~min}$ at $94^{\circ} \mathrm{C}, 1 \mathrm{~min}$ at $52^{\circ} \mathrm{C}, 1.5 \mathrm{~min}$ at $72^{\circ} \mathrm{C}$, a final extension for $8.5 \mathrm{~min}$ at $72^{\circ} \mathrm{C}$, and holding at $4^{\circ} \mathrm{C}$. PCR products were separated by electrophoresis on $1.5 \%$ agarose gels in $40 \mathrm{mM}$ Tris-acetate $(\mathrm{pH} 8.0)$ and 1 mM EDTA (TAE) buffer.

DNA cloning and sequencing. PCR products were purified using MicroSpin S-400HR columns (Amersham Pharmacia Biotech Inc., Piscataway, NJ) according to the instructions supplied by the manufacturer. The purified PCR products were ligated to the pGEM-Easy vector (Promega, Madison, WI), as instructed by the manufacturer, and transformed into competent Escherichia coli (JM109) cells.

Transformants were selected on Luria-Bertani (LB) agar plates containing ampicillin, isopropylthio- $\beta$-D-galactoside (IPTG) and 5-bromo-4-chloro-3-indolyl- $\beta$-D-galactoside (X-gal) (16). Individual clones were used to inoculate LB broth containing ampicillin and grown overnight at $37^{\circ} \mathrm{C}$ with shaking. Recombinant plasmids were purified using the Wizard Plus SV Minipreps DNA Purification System (Promega) according to the manufacturer's instructions. The purified plasmids were double digested with the restriction enzymes $\mathrm{NcoI}$ and $\mathrm{SacI}$, to confirm that inserts were of the desired sizes. Plasmids were sequenced using the automated DNA sequencer Prism Model 377 (Applied Biosystems) with fluorescentdye-labeled dideoxy terminators at ESPEC Oligo Service Corp., Tsukuba, Japan. After sequencing, the base sequences were translated to amino acid sequences with NCBI/GenBank yeast mitochondrial code.

PCR-restriction fragment length polymorphism. Fragments of the cytochrome $b$ gene, PCR amplified from strobilurinresistant and -sensitive isolates of cucumber powdery mildew, were treated with the enzyme EcoT14I (Takara Shuzo, Otsu, Japan) according to the manufacturer's protocol. Digests were run on $2 \%$ agarose gels with TAE duffer and stained with ethidium bromide. 


\section{RESULTS}

Detection of strobilurin-resistant isolates in cucumber powdery mildew. Sensitivities of fungal isolates to commercial formulations of azoxystrobin were first tested by leaf disk tests (Table 1). Disease development of the reference sensitive isolate $\mathrm{K}-7-2$ was $80 \%$ retarded by the fungicide at $0.01 \mu \mathrm{g} \mathrm{ml}^{-1}$ and completely inhibited at $10 \mu \mathrm{g} \mathrm{ml} \mathrm{m}^{-1}$. In contrast, the sensitivity of other isolates collected from commercial greenhouses in Shimodate, Ibaraki was much lower than that of the reference one. No growth inhibition was observed at $1 \mu \mathrm{g} \mathrm{ml}^{-1}$ and some isolates grew well at $100 \mu \mathrm{g} \mathrm{ml}{ }^{-1}$, the concentration recommended in practice. Resistant isolates were found not only in the strobilurintreated greenhouse (house A), but also in the untreated greenhouse (house B), located at a distance of $5.5 \mathrm{~km}$ in the same area. Two isolates in house A and five isolates from house B showed resistance to strobilurins. Sensitivity to kresoxim-methyl was also examined (Table 2) and cross-resistance to azoxystrobin clearly demonstrated. The reference isolate $\mathrm{K}-7-2$ was sensitive to kresoxim-methyl; however, growth of all other isolates was not suppressed, even at $138 \mu \mathrm{g} \mathrm{ml}^{-1}$, which is a concentration used in practice. When technical grade azoxystrobin was used (Table 1), growth of isolate K-7-2 was more strongly inhibited than with commercial formulations (Table 1), and no growth observed at $0.001 \mu \mathrm{g} \mathrm{ml}^{-1}$, the lowest concentration tested. Other isolates from Shimodate grew vigorously up to $1 \mu \mathrm{g} \mathrm{ml}^{-1}$. Sensitivity of these isolates was almost 10,000 times lower than that of the reference sensitive isolate. Cross-resistance to kresoxim-methyl was also confirmed using the technical grade of this fungicide (data not shown).

Next, foliar spray tests were carried out with potted cucumber plants. Growth of resistant isolate R-2 from house A in Shimodate was not controlled by commercial formulations of azoxystrobin at $100 \mu \mathrm{g} \mathrm{ml} \mathrm{l}^{-1}$, which is the practically used concentration, whereas the reference sensitive isolate K-7-2 was completely controlled even at $25 \mu \mathrm{g} \mathrm{ml}^{-1}$, one-fourth of the concentration recommended in practice (Table 1). In untreated control plots, disease severity on cucumber plants inoculated with R-2 was nearly equal to that on plants inoculated with K-7-2. In other experiments, disease development of resistant isolates R-2 and S-1 (from house B in Shimodate) was not suppressed by azoxystrobin at $100 \mu \mathrm{g} \mathrm{ml}{ }^{-1}$, but the isolate K-7-2 was completely controlled (data not shown).

Detection of strobilurin-resistant isolates in cucumber downy mildew. In foliar spray tests using commercial formulations of azoxystrobin at $100 \mu \mathrm{g} \mathrm{m}^{-1}$ a.i., the concentration used in practice, isolate $\mathrm{S}$ was completely controlled, whereas no ef-

TABLE 1 . Sensitivity of cucumber powdery mildew (Podosphaera fusca) isolates to azoxystrobin (Azo)



${ }^{a}$ Commercial, leaf = commercial formulation, leaf disk tests; Technical = technical grade, leaf disk tests; and Commercial, foliar $=$ commercial formulation, foliar spray tests.

${ }^{\mathrm{b}}$ K-7-2 = reference sensitive isolate; R-2 = resistant isolate from a greenhouse where strobilurin fungicides were applied four times between 1998 and 1999; $\mathrm{R}-5=$ resistant isolate from a greenhouse where strobilurin fungicides were applied four times between 1998 and 1999 ; S-1 to S-6 = resistant isolates from a greenhouse in which strobilurin fungicide was used only once in 1999 . Disease severity (DS) calculated as $[(5 A+4 B+3 C+2 D+E) / 5 F] \times 100$, where $A, B$, $C, D$, and $E$ are the number of leaf disks corresponding to the scales, 5, 4, 3, 2, and 1, respectively, and $F$ is the total number of leaf disks assessed.

${ }^{\mathrm{c}}$ Concentration recommended in practice.

${ }^{\mathrm{d}}$ Control with azoxystrobin at 25, 50, and $100 \mu \mathrm{g} \mathrm{ml}^{-1}$ a.i. was $100 \%$ for all levels for K-7-2 and 3.4, -20.8 , and $-17.4 \%$, respectively, for R-2.

TABLE 2. Sensitivity of cucumber powdery mildew isolates to the commercial formulation of kresoxim-methyl in leaf disk tests

\begin{tabular}{lccccc}
\hline & \multicolumn{3}{c}{ Isolate $^{\mathrm{a}}$} \\
\cline { 2 - 6 } Kresoxim-methyl $\left(\mu \mathrm{g} \mathrm{ml}^{-1}\right.$ a.i. $)$ & $\mathrm{K}-7-2$ & $\mathrm{R}-2$ & $\mathrm{~S}-1$ & $\mathrm{~S}-3$ & $\mathrm{~S}-4$ \\
\hline 0 & 100 & 100 & 100 & 100 & 100 \\
0.01 & 100 & 100 & 100 & 100 & 100 \\
0.1 & 100 & 100 & 100 & 100 & 100 \\
1.4 & 6.7 & 100 & 100 & 100 & 100 \\
13.8 & 0 & 100 & 100 & 100 & 100 \\
$138^{\mathrm{b}}$ & 0 & 100 & 100 & 100 & 100 \\
\hline
\end{tabular}

${ }^{\mathrm{a}}$ K-7-2 = reference sensitive isolate; R-2 = resistant isolate from a greenhouse where strobilurin fungicides were applied four times between 1998 and 1999; S-1 to S-6 = resistant isolates from a greenhouse in which strobilurin fungicide was used only once in 1999 . Disease severity (DS) calculated as [ $(5 A+4 B+$ $3 C+2 D+E) / 5 F] \times 100$, where $A, B, C, D$, and $E$ are the number of leaf disks corresponding to the scales, $5,4,3,2$, and 1 , respectively, and $F$ is the total number of leaf disks assessed.

${ }^{\mathrm{b}}$ Concentration recommended in practice. 
ficacy was recorded against the isolate $\mathrm{R}$ collected from Sanbu, Chiba (Table 3). In untreated control plots, disease severity was higher on plants inoculated with the resistant isolate as compared with the sensitive isolate. Cross-resistance of the isolate $\mathrm{R}$ to kresoxim-methyl (138 $\mu \mathrm{g} \mathrm{ml}^{-1}$ a.i.) was also confirmed (Table 4). In contrast, the sensitive isolate was effectively controlled with this fungicide.

PCR amplification and sequence analysis of cytochrome $\boldsymbol{b}$ gene. A single fragment, of $\approx 285 \mathrm{bp}$ in size, was produced with the primer RSCBF1 and RSCBR2, using genomic DNA from both cucumber powdery mildew and downy mildew isolates. The amplified products were purified, cloned, and then sequenced. The partial amino acid sequence of cytochrome $b$, deduced from gene sequences of strobilurin-sensitive and -resistant isolates of Podosphaera fusca is shown in Figure 1. In two sensitive isolates K-72 and Melon 1, the deduced amino acid at codon 143 (GGT) was glycine. In contrast, it was substituted with alanine (GCT) in two resistant isolates, R-2 and S-3, but not in resistant isolate S-1. Furthermore, substitutions in the deduced amino acid sequence of resistant isolates were also found in other part of the protein compared with the sensitive isolates. In three resistant isolates, replacements of leucine 130 by methionine, tyrosine 136 by tryptophan, and leucine 141 by phenylalanine were found.

Comparison of the partial nucleotide sequence of the cytochrome $b$ gene in Pseudoperonospora cubensis isolates revealed that a single point mutation was present in the sequence of all resistant isolates. A transversion from guanine (in two sensitive isolates S and FS) to cytosine at codon 143 was found in three resistant isolates of the pathogen, irrespective of the location from which the isolate was collected. Resistant isolates derived from Chiba (R), Miyazaki (MAZ-1), and Ibaraki (A1-9) all had the same mutation of GGT to GCT. It is suggested that a single point mutation at codon 143, resulting in substitution of glycine with alanine, correlated with resistance (Fig. 1).

All resistant isolates from both species contained methionine at position 130, tryptophan at position 136, phenylalanine at position 141 , and alanine at position 143 , except for isolate $S-1$, which retained glycine at position 143 .

PCR-restriction fragment length polymorphism. With cucumber powdery mildew, the restriction enzyme EcoT14I, having the recognition sequence $\mathrm{CCW}(\mathrm{A}$ or $\mathrm{T}) \mathrm{W}(\mathrm{A}$ or $\mathrm{T}) \mathrm{GG}$, clearly recognized the sequence CCTTGG (codon 135 to 136) in cytochrome $b$ gene of resistant isolates and produced two bands on an agarose gel after treatment. In contrast, PCR fragments of the gene, having the sequence CCTTAA at codon 135 to 136 amplified from sensitive isolates, were not digested with EcoT14I.

\section{DISCUSSION}

Strobilurin fungicides are site-specific inhibitors; therefore, these fungicides are considered to have a high potential risk for resistance development in pathogen populations when they are used in practice (15). Therefore, baseline sensitivities of some pathogens to strobilurin fungicides were examined $(4,13,23)$. Fur-

TABLE 3. Sensitivity of cucumber downy mildew isolates to the commercial formulation of azoxystrobin in foliar spray tests

\begin{tabular}{lccc}
\hline & & \multicolumn{2}{c}{ Control $(\%)^{\mathrm{b}}$} \\
\cline { 3 - 4 } Isolate $^{\mathrm{a}}$ & Azoxystrobin $\left(\mu \mathrm{g} \mathrm{ml}^{-1}\right.$ a.i. $)$ & 1st leaf & 2nd leaf \\
\hline $\mathrm{S}$ & $100^{\mathrm{c}}$ & $100(53.3)$ & $100(20)$ \\
$\mathrm{R}$ & $100^{\mathrm{c}}$ & $0(100)$ & $-7.6(86.7)$ \\
\hline
\end{tabular}

${ }^{a} \mathrm{~S}=$ sensitive isolate and $\mathrm{R}=$ resistant isolate from a field where strobilurin fungicides were applied three times in 1999.

${ }^{\mathrm{b}}$ Value in parenthesis is disease severity (DS) on untreated control. Control (\%) of individual fungicides was calculated as [(DS on untreated leaves - DS on treated leaves)/DS on untreated leaves] $\times 100$.

${ }^{c}$ Concentration recommended in practice. thermore, strobilurin sensitivities of pathogens were monitored in experimental fields where strobilurin fungicides were extensively used to determine how quickly resistant isolates emerged and caused a problem of control failure. Kunz et al. (10) mentioned that no isolates of Venturia inaequalis, the cause of apple scab, resistant to kresoxim-methyl, were detected from an orchard in which 54 kresoxim-methyl treatments were made over 6 years.

To avoid resistance, growers in Japan received guidelines from manufacturers for both kresoxim-methyl and azoxystrobin. Although these guidelines were followed by most growers, a rapid decline in fungicide efficacy against cucumber powdery mildew was reported between late 1998 and early 1999. The cause of control failure was carefully checked and, as a result, it was suggested that the appearance of resistant fungal isolates played an important role in the poor performance of strobilurin fungicides $(8,12,21)$. In the present study, results from leaf disk tests and pot experiments clearly showed the existence of powdery mildew isolates bearing high strobilurin resistance. Isolates resistant to azoxystrobin also showed cross-resistance to kresoxim-methyl.

Highly strobilurin-resistant isolates of powdery mildew were detected not only from greenhouses, where this group of fungicides was applied a couple of times per crop, but also from greenhouses in which only one application of strobilurins was made since their introduction. Subsequent monitoring in Ibaraki also showed that resistant isolates were already widely distributed regardless of the absence or presence of strobilurin fungicides, probably a result of stability of resistance and long-distance dispersal of fungal conidia by wind. The data will be reported in detail elsewhere (H. Ishii, T. Sugiyama, K. Nishimura, and Y. Ishikawa, unpublished data).

In cucumber-growing areas, both kresoxim-methyl and azoxystrobin have commonly been used for the control, not only of powdery mildew, but also of downy mildew and other pathogens. Therefore, it was likely that resistant isolates of other pathogens would also appear. In fact, such isolates were detected from cucumber fields and greenhouses where downy mildew could not be adequately controlled by strobilurins. Clear cross-resistance between azoxystrobin and kresoxim-methyl was recognized in isolates of downy mildew. Heaney et al. (5) briefly mentioned that resistant populations of both cucumber powdery and downy mildew were present at almost all locations sampled in Japan.

The rapid appearance of fungicide resistance, as was the case in benzimidazole resistance, suggests the occurrence of a single resistance-conferring point mutation in the gene encoding the fungicide-targeted protein (6). Mitochondria of the strobilurin A (from which synthetic strobilurin fungicides have been developed) producing basidiomycetes Strobiluris tenacellus and Mycena galopoda exhibit natural resistance to inhibitors of the cytochrome $b c_{1}$ complex. Kraiczy et al. (9) carried out comparative sequence analysis of regions of cytochrome $b$ and suggested replacements of glycine 143 by alanine and glycine 153 by serine in $M$. galopoda and amino acid 254 by glutamine and asparagine 261 by aspartate in S. tenacellus, confer resistance. They concluded that the replacements at positions 143 and 153 were very likely to confer

TABLE 4. Sensitivity of cucumber downy mildew isolates to the commercial formulation of kresoxim-methyl $(\mathrm{K}-\mathrm{m})$ in foliar spray tests

\begin{tabular}{lcccc} 
& & \multicolumn{3}{c}{ Control $(\%)^{\mathrm{b}}$} \\
\cline { 4 - 5 } Isolate $^{\mathrm{a}}$ & $\mathrm{K}-\mathrm{m}\left(\mu \mathrm{g} \mathrm{m} \mathrm{m}^{-1}\right.$ a.i. $)$ & 1st leaf & 2nd leaf & 3rd leaf \\
\hline $\mathrm{S}$ & $138^{\mathrm{c}}$ & $93.3(100)$ & $92.8(93.3)$ & $100(40)$ \\
$\mathrm{R}$ & $138^{\mathrm{c}}$ & $0(100)$ & $0(93.3)$ & $-33.3(33.3)$ \\
\hline
\end{tabular}

a $\mathrm{S}=$ sensitive isolate and $\mathrm{R}=$ resistant isolate from a field where strobilurin fungicides were applied three times in 1999.

$\mathrm{b}$ Value in parenthesis is disease severity (DS) on untreated control. Control (\%) of individual fungicides was calculated as [(DS on untreated leaves - DS on treated leaves)/DS on untreated leaves] $\times 100$.

c Concentration recommended in practice. 
resistance of the $M$. galopoda cytochrome $b c_{1}$ complex to strobilurin compounds. These two exchanges seemed to affect binding of strobilurin A, if at all, to a much lesser extent.

In plant pathogenic fungi, Zheng and Köller (25) first characterized the mitochondrial cytochrome $b$ gene from a strobilurinsensitive isolate of $V$. inaequalis. Subsequently, Olaya et al. (14) found differential responses of germinating $V$. inaequalis conidia to kresoxim-methyl in vitro; however, no sequence alterations in cytochrome $b$ gene of the less-sensitive isolate were detected compared with the sensitive reference. More recently, Zheng et al. (26) obtained a strobilurin-resistant isolate of this fungus in the laboratory and found that the laboratory mutant possessed a single amino acid substitution from glycine to alanine at residue 143 in cytochrome $b$ protein. In this study, the same amino acid substitution has been found in field isolates of cucumber downy mildew. In this Oomycete pathogen, one base change from guanine to cytosine commonly occurred in strobilurin-resistant isolates collected from greenhouses or fields at separate locations, $\approx 900 \mathrm{~km}$ apart (from Chiba or Ibaraki to Miyazaki), suggest that this point mutation occurred independently. The mutation also was detected in two resistant isolates of cucumber powdery mildew. In strobilurin-sensitive isolates of this fungus, the deduced amino acid at codon 143 is glycine. Therefore, substitution with alanine at this position, in two resistant isolates, suggests that this alteration in the cytochrome $b$ gene closely related with resistance in cucurbit powdery mildew. However, one resistant isolate possessed a sensitive sequence at codon 143 of the protein.

Subtle mechanisms other than point mutations in the targetencoding gene might be involved in resistance of such isolates. Very recently, sequence data of the cytochrome $b$ gene were reported from isolates of Mycosphaerella fijiensis, the cause of black Sigatoka of banana, collected from an experimental field (19). A single amino acid change from glycine to alanine at position 143 was found in one strobilurin-resistant isolate. Moreover, the same single point mutation was identified in resistant isolates of Blumeria (Erysiphe) graminis DC. f. sp. tritici on wheat (20). These data strongly suggested that resistance to strobilurin fungicides in field isolates of plant pathogens is mainly due to a target site alteration (5).

The rapid rate of strobilurin-resistance development is somewhat surprising because official tests on disease control for registration of the fungicides in both fields and greenhouses did not

129

146

Podosphaera fusca

K-7-2: F LGYGLPY GQMSLWGATV

Melon 1: F LGYGLPY GQMSLWGATV

R-2: FMGYGLPWGGMSFW

S-1: FMGYGLPWGQMSEWGATV

S-3: FMGYGLPWGQMSEWEAATV

Pseudoperonospora cubensis

S: $\quad$ FMGYVLPWGQMSFWGATV

FS: FMGYVLPWGQMSFWGATV

R: FMGYVLPWGQMSFWAATV

MAZ-1: FMGYVLPWGQMSFWAATV

A1-9: FMGYVLPWGQMSFWAATV

Fig. 1. Partial alignments (positions 129 to 146) of the deduced amino acid sequence of the cytochrome $b$ from two strobilurin-sensitive (K-7-2, reference; Melon 1, from Miyazaki) and three strobilurin-resistant isolates (R-2, S-1, and S-3, all from Ibaraki) of Podosphaera fusca, and two strobilurin-sensitive (FS, reference; $\mathrm{S}$, isolate from Chiba) and three strobilurin-resistant isolates (R, from Chiba; A1-9, from Ibaraki; MAZ-1, from Miyazaki) of Pseudoperonospora cubensis. Sites of amino acid substitution are underlined. indicate a high resistance risk. The targeted cytochrome $b$ protein is encoded by mitochondrial DNA (mtDNA), which is thought to mutate in higher frequency than nuclear DNA (11). The speed of evolution (i.e., mutation frequency) in mtDNA is generally believed to be approximately 10 times higher than in nuclear DNA. Intraspecific diversion of mtDNA is also well known (22). In fact, in this study, amino acid substitutions were detected in regions of cytochrome $b$ protein other than codon 143, particularly in isolates of cucumber powdery mildew. In addition to these characteristics of mtDNA, the biological nature of this fungus (i.e., high population density and rapid multiplication as well as severe disease pressure) would have contributed to selecting the fungicide-resistant isolates in greenhouses. Another possibility is that distinct fungal species of powdery mildew from Podosphaera fusca, inherently insensitive to strobilurin fungicides, have emerged. In France, two different fungi, Erysiphe cichoracearum and $P$. fusca, were reported to cause powdery mildew on cultivated cucurbits, with the former commonly found in temperate zones (2). Moreover, E. cichoracearum differed from $P$. fusca in pathogenicity and sensitivity to some fungicides. Therefore, morphological characteristics of the fungal isolates employed in this work were examined and shown to be P. fusca (Y. Sato and H. Ishii, unpublished data). Strobilurin-resistant isolates of this fungus also coincidentally possessed altered amino acids at positions 130, 136, and 140 in cytochrome $b$ protein (Fig. 1). Although these amino acid substitutions did not seem to result in resistance, because sensitive isolates of cucumber downy mildew had the same amino acid sequences, the sequence CCTTGG (codon 135 to 136) of cytochrome $b$ gene in resistant isolates were clearly distinguished by PCR-restriction fragment length polymorphism analysis using the restriction enzyme EcoT14I. Further molecular characterization of this pathogen will be carried out in near future.

\section{ACKNOWLEDGMENTS}

We thank Y. Nakazawa, ZEN-NOH, S. M. Dale, Zeneca Agrochemicals, H. Sugiyama, J. A. Kita-Tsukuba, S. Nishino, Ibaraki Plant Protection Station, Y. Tomita, Horticultural Research Institute (Ibaraki Agricultural Center), Y. Imamura, Miyazaki Agricultural Experiment Station, and S. Umemoto, Chiba Experimental Agriculture Station, for providing useful information and cooperation in the sampling of diseased materials; Y. Sato, College of Technology, Toyama Prefectural University, for cooperation in the identification of Podosphaera fusca; and T. Joseph-Horne, H. J. Cools, and Y. Ishikawa for their technical advice, useful discussion, and preparing plant materials.

\section{LITERATURE CITED}

1. Anonymous. 1998. Strobilurin-resistant mildew found in Germany. AGROW 318:11.

2. Bardin, M., Carlier, J., and Nicot, P. C. 1999. Genetic differentiation in the French population of Erysiphe cichoracearum, a causal agent of powdery mildew of cucurbits. Plant Pathol. 48:531-540.

3. Erichsen, E. 1999. Problems in mildew control in northern Germany. Getreide 1:44-46.

4. Fujita, N., Hamada, K., Inagaki, M., Enoyoshi, T., Miyahara, T., Kojiguchi, S., Ogasawara, K., Kadota, G., Dale, S. M., and Takamatsu, S. 1999. Strobilurin baseline determination and resistance monitoring. (Abstr.) Ann. Phytopathol. Soc. Jpn. 65:692.

5. Heaney, S. P., Hall, A. A., Davies, S. A., and Olaya, G. 2000. Resistance to fungicides in the QoI-STAR cross-resistance group: Current perspectives. Proc. BCPC Conf. Pests \& Dis. 2000:755-762.

6. Ishii, H. 1995. Monitoring of fungicide resistance in fungi: Biological to biotechnological approaches. Pages 493-503 in: Molecular Methods in Plant Pathology. R. P. Singh and U. S. Singh, eds. CRC Press, Boca Raton, FL.

7. Ishii, H., Fraaije, B. A., Noguchi, K., Nishimura, K., Takeda, T., Amano, T., Joseph-Horne, T., and Hollomon, D. W. 2000. Cytochrome b genes in phytopathogenic fungi and their involvement in strobilurin resistance. (Abstr.) Jpn. J. Phytopathol. 66:183.

8. Ishii, H., Noguchi, K., Tomita, Y., Umemoto, S., and Nishimura, K. 1999. Occurrence of strobilurin resistance in powdery mildew and downy mildew on cucumber. (Abstr.) Ann. Phytopathol. Soc. Jpn. 
65:655.

9. Kraiczy, P., Haase, U., Gencic, S., Flindt, S., Anke, T., Brandt, U., and von Jagow, G. 1996. The molecular basis for the natural resistance of the cytochrome $\mathrm{bc}_{1}$ complex from strobilurin-producing basidiomycetes to center $\mathrm{Q}_{\mathrm{p}}$ inhibitors. Eur. J. Biochem. 235:54-63.

10. Kunz, A., Lutz, B., Deising, H., and Mendgen, K. 1998. Assessment of sensitivities to anilinopyrimidine- and strobilurin-fungicides in populations of the apple scab fungus Venturia inaequalis. J. Phytopathol. 146: 231-238.

11. Nakazawa, T., and Asami, K. 1995. Mitochondria, 2nd ed. Tokyo University Press, Tokyo.

12. Ogasawara, K., Enoyoshi, T., Miyahara, T., Kojiguchi, S., Kadota, G., Takamatsu, S., and Dale, S. M. 1999. Cucurbit powdery mildew resistant to strobilurins. (Abstr.) Ann. Phytopathol. Soc. Jpn. 65:655.

13. Olaya, G., and Köller, W. 1999. Baseline sensitivities of Venturia inaequalis populations to the strobilurin fungicide kresoxim-methyl. Plant Dis. 83:274-278.

14. Olaya, G., Zheng, D., and Köller, W. 1998. Differential responses of germinating Venturia inaequalis conidia to kresoxim-methyl. Pestic. Sci. 54:230-236.

15. Russell, P. E. 1999. The assessment of resistance risk and registration of fungicides in the EU. Abstr. 9th Symp. Res. Commit. Fungic. Resist. (Phytopathol. Soc. Jpn.) 9-18.

16. Sambrook, J., Fritsch, E. F., and Maniatis, T. 1989. Molecular Cloning: A Laboratory Manual. 2nd ed. Cold Spring Harbor Laboratory, Cold Spring Harbor, NY.

17. Sauter, H., Ammermann, E., Benoit, R., Brand, S., Gold, R. E., Grammenos, W., Köhle, H., Lorenz, G., Müller, B., Röhl, F., Schirmer, U., Speakman, J. B., Wenderoth, B., and Wingert, H. 1995. Mitochondrial respiration as a target for antifungals: Lessons from research on strobilurins. Pages 173-191 in: Antifungal Agents: Discovery and Mode of Action. G. K. Dixon, L. G. Copping, and D. W. Hollomon, eds. BIOS Scientific Publishers, Oxford, UK.

18. Schepers, H. T. A. M. 1984. Persistence of resistance to fungicides in Sphaerotheca fuliginea. Neth. J. Plant Pathol. 90:165-171.

19. Sierotzki, H., Parisi, S., Steinfeld, U., Tenzer, I., Poirey, S., and Gisi, U. 2000. Mode of resistance to respiration inhibitors at the cytochrome $\mathrm{bc}_{1}$ enzyme complex of Mycoshaerella fijiensis field isolates. Pest Manage. Sci. 56:833-841

20. Sierotzki, H., Wullschleger, J., and Gisi, U. 2000. Point mutation in cytochrome $\mathrm{b}$ gene conferring resistance to strobilurin fungicides in Erysiphe graminis f. sp. tritici field isolates. Pestic. Biochem. Physiol. 68:107-112.

21. Takeda, T., Kawagoe, Y., Uchida, K., Fuji, M., and Amano, T. 1999. The appearance of resistant isolates to strobilurins. (Abstr.) Ann. Phytopathol. Soc. Jpn. 65:655.

22. Taylor, J. W. 1986. Fungal evolutionary biology and mitochondrial DNA. Exp. Mycol. 10:259-269.

23. Wong, F. P., and Wilcox, W. F. 2000. Distribution of baseline sensitivities to azoxystrobin among isolates of Plasmopara viticola. Plant Dis. 84:275-281.

24. Ypema, H. L., and Gold, R. E. 1999. Kresoxim-methyl: Modification of a naturally occurring compound to produce a new fungicide. Plant Dis. 83:4-19.

25. Zheng, D., and Köller, W. 1997. Characterization of the mitochondrial cytochrome b gene from Venturia inaequalis. Curr. Genet. 32:361366.

26. Zheng, D., Olaya, G., and Köller, W. 2000. Characterization of laboratory mutants of Venturia inaequalis resistant to strobilurin-related fungicide kresoxim-methyl. Curr. Genet. 38:148-155. 